\title{
Scripting development through formalization: accounting for the diffusion of village savings and loans associations in Tanzania
}

DOI:

10.1111/1467-9655.12966

\section{Document Version}

Accepted author manuscript

Link to publication record in Manchester Research Explorer

Citation for published version (APA):

Green, M. (2018). Scripting development through formalization: accounting for the diffusion of village savings and loans associations in Tanzania. Journal of the Royal Anthropological Institute. https://doi.org/10.1111/1467-

9655.12966

\section{Published in:}

Journal of the Royal Anthropological Institute

\section{Citing this paper}

Please note that where the full-text provided on Manchester Research Explorer is the Author Accepted Manuscript or Proof version this may differ from the final Published version. If citing, it is advised that you check and use the publisher's definitive version.

\section{General rights}

Copyright and moral rights for the publications made accessible in the Research Explorer are retained by the authors and/or other copyright owners and it is a condition of accessing publications that users recognise and abide by the legal requirements associated with these rights.

\section{Takedown policy}

If you believe that this document breaches copyright please refer to the University of Manchester's Takedown Procedures [http://man.ac.uk/04Y6Bo] or contact uml.scholarlycommunications@manchester.ac.uk providing relevant details, so we can investigate your claim.

\section{OPEN ACCESS}


SCRIPTING DEVELOPMENT THROUGH FORMALIZATION:

ACCOUNTING FOR THE DIFFUSION OF VILLAGE SAVINGS

ASSOCIATIONS IN TANZANIA

Keywords: village savings associations, financial institutions, ritual, international development, East Africa, Tanzania. 


\section{Introduction}

The anthropological literature on development is expanding. Analyses of large scale programmes (e.g Ferguson 1990; Li 2007) have been supplemented by more recent explorations of development technologies, organisations and relations (e.g Krause 2015; Watanabe 2015). Far fewer studies consider the various ways in which people engage with 'development' as it is contextually defined. Development as a project of improvement is not the prerogative of states and development agencies but is personalised through the aspirational practices of ordinary citizens as they seek to create a better future (Appadurai 2004). Financial practices are central to this endeavour (Green et al 2012; James 2014: 22). A development form which has proliferated markedly over the past decade is one intentionally designed to flourish beyond the projects which disseminate it (Allen 2002: 15; Allen 2006). Village savings and loan associations (VSLA) consist of between twelve and thirty people who contribute money in an annual cycle in order to provide loans to members. Disseminated through development initiatives since the 2000's they have become an accepted part of the financial landscape across the global south. ${ }^{1}$ The greatest number are in Sub Saharan Africa, where an estimated nine million people are members (le Polain, Sterck \& Nyssens 2017: 162).

The rapid increase in Village Savings and Loan Associations owes much to organisational techniques through which they are propagated. A system for 
setting up self organised savings associations was developed by CARE International staff in the early 1990s. What is referred to by practitioners as the 'VSLA methodology' has since become the standard organisational template for their operation across the development sector, supported by an expanding infrastructure of resources and expertise. (Allen \& Staehle 2005; Malkamaki 2015). ${ }^{2}$ Although the majority of programmes disseminating this model are typically of two or three years' duration they have been extremely successful in establishing savings groups, even in areas where the prior existence of local forms of savings association was very limited. What is perhaps more remarkable is the extent to which these newly created organisations sustain themselves through annual savings cycles and provide fertile ground for the formation of new groups.

VSLA groups are undergoing similar trajectories of expansion in in many countries in Africa and South Asia (Rutherford \& Arora 2009: 96; Hendricks and Chidiac 2011). Advocates of village savings associations explain this expansion in terms of their effectiveness as a financial technology which helps members achieve more control over their money (Allen 2006; Ayango et al 2007). However, to explain the diffusion of savings associations only in terms of popularising the practice of saving does not account for the phenomenal increase in this particular form of organisation. The proliferation of village savings associations is not simply a result of donor funding and insertion within large scale financial inclusion programmes. Nor can it be explained by the alignment of financialization narratives with neoliberal 
ideologies of personal economic empowerment (Roy 2010; Schwittay 2011). The specifics of organisational form play a pivotal role in their diffusion (Bouman 1995a, 1995b; 1997).

The VSLA 'methodology' comprises a portfolio of artefacts and routines devised to enable the self replication of savings associations by equipping people with the organisational and financial instruments they need to form and manage them. Crafted by specialists with extensive knowledge of the financial practices of the rural poor, it uses the workings of a saving group conceived within a CARE project in Niger as an exemplary form refined through numerous iterations from implementation at scale (Grant \& Allen 2002). The resulting template selectively draws on the organisational practices common across low income countries through which groups of people pool resources, making them available at various times to members of the group. ${ }^{3}$ Small scale savings groups occur across Africa, Asia and Latin America. Diverse variations of the savings association form are composites of indigenous and bureaucratic institutional forms, characterised by high levels of formalization. Savings groups used standard meeting formats, formal offices and titles and rehearsed rhetorical devices (e.g Bouman 1995a; 1995 b; Delancey 1977:319; Ardener 1964: 210;). Accounts of self organised savings associations consistently remark on the ceremonial and ritual aspects of their practice (e.g. Bouman \& Harteveld 1976: 108; James 2015: 12; 2012: 26; Rodima-Taylor 2014: 570). 
This paper uses insights from anthropological scholarship on ritual to explore the on-going extension of village savings and loans associations as a particular organisational form in rural southern Tanzania. Anthropological accounts of ritual which focus only on its representational qualities obscure the organisational potential of ritual practice in generating and reproducing of social forms (Robbins 2009). The organisational potential of ritual has long been recognised by sociologists seeking to explain the institutionalisation of social practices (Goffman 1995) and the diffusion of organisational forms. Sociological theories associate ritualization with institutional isomorphism through the mimetic replication of formal organisations (Di Maggio \& Powell 1983; Meyer \& Rowan 1977) and or as a vehicle for the creation of modern organisational forms in response to cultural globalisation (Strang \& Meyer 1993: 503; Meyer 2010). An ethnographically situated analysis of the extension of village savings associations provides an opportunity explore the practices through which people organise new social arrangements in emergent institutional fields created through the conjunction of development programming and financialization (Hart \& Oritz 2014: 476). Self organised savings associations adopt the organisational properties of ritual to generate and sustain autonomous local institutions (Handelman 2004: 9).

Prioritising the disciplinary aspects of ritual as the basis of organisational routines emphasises its institution building potential (Asad 1993: 58-79; Robbins 2009). It sheds light on the rapid expansion of savings associations and their isomorphic qualities, as well as their success as a vehicle for the 
social performance of saving. The ritualization of group practices renders the regulatory activities of saving groups memorable and replicable (Robbins 2009: 64; Goffman 2005: 44) and simultaneously enacts the formalities necessary for accounting for returns on savings (Guyer 2004). In performing a separation between people's social identities and their identities as account holders, and between monies collected by savings groups for different purposes, the ritualization of savings group practices operates as a 'framing' device through which money can appear to be temporarily disentangled from the social relations which could preclude its subjection to financial rules for the accumulation of value (Callon 1998). Members of savings associations use ritual as an organisational device to periodically instantiate an institutional space in which persons assume an identity as 'savers', conceptualised within financialisation narratives as empowered agents of their own development (Schwittay 2011), through adherence to rules which restrict their personal and financial agency.

\section{Savings Associations and Self Organising}

Small scale savings associations are a global institutional form, ranging from groups of four or five people who take turns to access one another's contributions to the accumulating savings and credit associations which manage lending, saving and social insurance for several hundred people (Ardener \& Burman 1995; Bouman 1997;1995 b); Ardener 2014). Examples familiar to anthropologists include the Mexican tanda (Cope \& Kurtz 1980) , the Cameroonian njangi (de Lancey 1977), the Nigerian esusu; and the 
Indonesian arisan (Geertz 1962). Most research on savings associations has focused on the mobilization of savings, hence the body of work exploring the operation of rotating savings and credit associations which are differentiated from those which are organised around accumulating funds (Hospses 1992:372). Associations of both types have been co-opted into modernization imaginaries, from the 1960's as `middle rung' financial institutions between agrarian and modern economies (Geertz 1962) and, from the 1970's, as development instruments (Devereux, Pares \& Best 1987). ${ }^{4}$

Savings associations may be managed by agents, as in Indian chit funds or, as in women's micro finance groups, integrated into a wider system of intermediary financial institutions. Groups which are organised by and obtain their capital from members are member managed autonomous financial institutions which do not depend on external organisations for funds or regulation (Bouman 1997: 2; 1995b:374). Such groups in Sub Saharan Africa organise themselves through regular meetings. Because self organisation becomes more complex the greater number of members, groups impose limits on membership (Bahre \& Smets 1999: 59) or subdivide into smaller groups (Bascom 1952: 64; Burman \& Lembete 1995:34). Savings associations which manage themselves and generate their own capital exhibit a paradoxical quality. One the one hand, because it is people that ....make rules, adapt rules and change rules' groups are free to adapt and to change the ways they operate (Hospses 1992: 388). On the other, because people 
very often can't be counted on in relation to money, groups operate through very explicit rules and sanctions (Bahre \& Smets 1999; (Bouman 1997: 2-5).

Shirley Ardener's institutional analysis of rotating savings and credit associations in West Africa and East Asia highlights the centrality of organisational routine at savings group meetings. Meetings were rule governed, with sanctions for defaulters and those who did not respect the proper order of procedure. Ceremonial was important. Some groups wore uniforms. Meetings had a scripted quality accentuated by strict order and rhetoric from leaders. Rules, regulations and offices created stability of organisational form in a context of changing membership and provided a disciplinary framework for the behaviour of members who had to trust one another. Regular meetings were occasions for paying in member contributions and public opportunities for witnessing who had how much of group member's money (1964:210-12).

More recent descriptions of self organised savings clubs in South Africa emphasise their ongoing concern with discipline, public performance and formalisation (Bahre \& Smets 1999; James 2012;2014;2015: 11). Detlev Krige shows how a group of young men serious about 'making money work' for them sought to transition their informal saving practices into those of an established stokvel through self consciously adopting some of the practices which members associated with formal financial institutions. Regular meetings, differentiated by dress and behaviour from everyday activity, 
displayed a 'near fixation with rules, constitutions and fines' (Krige 2014: 77). These kinds of practices are not evidence of institutional isomorphism as a mimetic response to a changed organizational nal field (di Maggio \& Powell 1983). Nor are they explicable only in terms of 'theorised diffusion' where newly available organisational models fulfil actors' changing understandings of their social worlds (Strang \& Meyer 1993:500 ). On the contrary, what Krige refers to as 'formalization from below' is an instrument for the purposive creation of effective social arrangements.

People involved in savings groups used formalisation to create `an organisational space that stood normatively and practically in opposition the challenges of everyday life ...' in Sowetan townships, delineating a boundary between contractual relations among group members and informal relations beyond it (2014:78). Embodied ideals of self discipline enacted in saving club practices extended beyond meetings, making it more possible for members to believe that they can 'count on one another' in conditions of endemic interpersonal distrust (Bahre \& Smets1999). Savings association practices sustained the performance of extreme compliance with group regulations in deliberate contrast to the unstructured norms of everyday financial and social interaction.

\section{Ritual and Social Scripting}

The organisation of savings associations through public meetings at which behaviour is scripted and disciplined has striking similarities to accounts by 
anthropologists which reassert the organisational effects of ritual practice. Talal Asad's investigation of the practices of medieval Christian monks reveals ritual to be primarily a 'script for repeating practice', rather than as text to be interpreted (1993: 57). Ritual as disciplinary practice (Asad 1987: 164) is an instrument for the explicit delineation of social arrangements articulated through regulated organisational routines. The explicit attention to social ordering in ritual is not necessarily otherworldly. Rather, it may accentuate an idealized order based on present forms hence ritual can seem to hold in abeyance or slow down the flow of 'chaotic actuality' (Kapferer 2004: 47-51).

The inscription of social orderings through ritual has multiple possibilities in terms of alignment or disjuncture with existing social forms. Encompassing bodily and personal discipline enacts the monks' totalising immersion in religious order (Asad 1987:164). More usually, ritual social orders present a contrast of some sort with existing social arrangements. Ritual can appear to have a distinct temporal dimension; in Maurice Bloch's exposition of Merina funerary rituals bringing the social order of long dead ancestors, and their generative powers, into the present (1977). It may also invoke imagined future social worlds. Joel Robbins shows how Pentecostal churches use ritual forms to bring into being the desired forms of sociality which sustain and extend their congregations (2009: 560). 
Robbins' analysis has important implications for the study of ritual. In contrast to the more usual anthropological positioning of ritual solely within frameworks of domination it draws attention to the agentive potentiality of ritual as a form of action through which people can create autonomous organisations, as opposed to being organised (2015: 28). This potentiality arises from the extent to which the principles through which a ritual is organised are contained within the ritual form itself, what Handelman refers to as its `self organising' properties (2004: 11). This cannot, of course, be a property of ritual but of the ways in which people in specific historical and social contexts use ritual practices to enact particular institutional forms and the extent, or otherwise, of their disjuncture from existing social orders (Law \& Singleton 2013: 264). The category of ritual from this perspective is not restricted to religious institutions, nor to the domain of symbolic action. Ritual as an organisational device recurs in the practice of revolutionary movements (Thomassen 2013), in the behavioural scripting of state agencies (Law \& Singleton 2013: 264) and in everyday interactions (Goffman 20052.

I argue in this paper that ritual's social productivity and organisational potential explains the practices of self organized savings associations in Tanzania and elsewhere which use extreme formalisation to delineate and display in public the idealized social order of the savings group as comprising rule governed and predictable relations between account holders and their money. This is not primarily a matter of financial self discipline and the regularisation of everyday habits (Bahre \& Smets 1999), but of 
demonstrating the rules through which the financial order of the savings group could yield predictable returns in contrast to the contingency, negotiability and secrecy of everyday relations around money.

Ritualization has added value for systems of financial ordering which require multiple demarcations of relations: between flows of money and categories of persons, and between money 'earmarked' for different purposes (Zelizer 1989; 2012). In performing a closed interactional space around sets of relations (Kapferer 1979) ritual renders explicit core principles of social ordering y). Michel Callon's theorization of 'framing', in which the elements which comprise the frame are simultaneously a conduit for overflows, is particularly appropriate for understanding the disciplinary practices of self organising savings groups (1998: 254). Savings groups practices use repetition and regulation to perform the restricted social and financial agency of the group member who should adhere to definite rules about the destination and allocation of money. The VSLA methodology acknowledges this practically in its use of formalisation, discipline and repetition to script the organisation of saving associations (e.g. Vanmeenen \& Bavois 2011). Approaching ritual as disciplinary practice through which groups organise themselves as financial institutions explains the characteristic form of savings associations and their replication. 


\section{Saving as Development in in Tanzania}

Tanzania is an East African country for many years associated with extreme poverty which is now experiencing rapid rates of economic growth. The colonial and postcolonial history of Tanzania has been consistently oriented towards development as national objective. Julius Nyerere's socialist policies in the decades after Independence attempted to target the three enemies of 'poverty, ignorance and disease' with forced villagization and nationalisation policies. Accelerating economic collapse from the 1970s lead to imposition of structural adjustment from the late 1980s (Lugalla 1997). Protracted dependence on international aid ensued, accompanied by gradual political and economic liberalisation( Green 2014).

Rotating savings associations known as upato have a recorded presence in Tanzania from the 1950s (Ardener 1964), rising in popularity during the during the 1980s as a means to address the cash shortages precipitated by the shrinking economy (Tripp 1994:113). They have been promoted by NGOs as a means of helping women access credit since the 1970s. Accumulating savings associations of the VSLA type which offer interest and more flexible borrowing assumed precedence in development programming internationally from the early 2000s. They have been grasped with enthusiasm by women's economic empowerment activists and by the government striving to reclaim ownership of its national development agenda through reduced reliance on donor finance and strong ideological commitment to growth through productivity. ${ }^{5}$ An estimated 200,000 hisa 
(share) groups, also called VICOBA or SILC after the acronyms used by the agencies which initially introduced them, ${ }^{6}$ comprise an emergent organizational field of local financial institutions with more than one million members (Brown et al 2015:8)7

At the time of my first fieldwork in the early 1990s in the highland villages of a rural district in the south east of the country there were no savings associations of the kind now disseminated through NGO programmes. The development office of the Catholic church introduced the savings association model to a single village in the mid 2000s. Two groups were formed, but there was no expansion. The situation changed after CARE's Access Africa financial inclusion programme undertook a systematic intervention between 2009 and 2011 to promote savings associations using trained local facilitators. By 2012, there were 344 savings associations rising to 420 a year later. There were over 500 in 2015.8

\section{Cash, Contributions and Cooperation}

Ulanga is typical of formerly peripheral agricultural districts in Tanzania which are being reintegrated into a fast changing national economy through the conjunction of natural resource extraction, improved road networks and growing urban demand for food. Most of its population of around 151,0009 are smallholder farmers working with hand hoes on scattered holdings to produce maize, beans and groundnuts. Farm incomes are insufficient to meet rising living costs. Men supplement their incomes through casual labour, 
artisanal mining and petty trade. Women earn cash from selling market vegetables, beer brewing and food processing. Many households resort to occasional help from urban relatives to meet out of the ordinary expenses.

In a milieu where livelihoods are assembled piece by piece, concern with the flow of cash -one's own and between other people- is a constant preoccupation. The flow of money has profound moral significance as an index of the quality of a person and their relationships. Money should flow between people, through contributions to life cycle events and marriage payments and through the circulation which is the basis of the economy (Rowlands 1995: 118;). Responsible use of money should make `money generate money' (zalisha- literally produce/ breed) through circulation (uzunguko) which allows other people to use it (Guyer 2012). These dynamics structure the social economy of Ulanga and the utilisation and perception of savings groups.

Control over money conveys agency in constituting the moral self relationally. Who gets what money, and from whom, is the outcome of contingent and uncertain relationships which are continually remade. Ability to choose when and how one gives money to another person is a source of power and a negotiating position in a situation where individuals are perpetually enmeshed in multiple obligations (Guyer 2004; Durham 1995: 116). To say that a person has 'uwezo' ability is a way of saying that they have money. A person with little money is has less agency but can still be 
seen to use money responsibly to perform social relations. The generative power of money means that it is extremely private, even between domestic partners who may choose to keep assets and cash 'secret and separate' (Geheb et al 2008). Public discourse about money draws attention to the importance of using money responsibly(Kusimba et al 2016).

Everyday transactions involving money are oriented towards wider relations within and beyond the household. These include payments of cash at various stages of the marriage process, helping with medical and education costs of one's immediate and extended family and responding to direct requests for help (-omba msaada) with everyday needs ('money for salt') from relatives and neighbours. People also have to be seen to contribute, in money or foodstuffs, to weddings, funerals and the annual memorial events for dead relatives and neighbours, in addition to multiple fundraising efforts of churches and village government. This kind of public contribution, ideally accompanied by personal engagement, in attending funeral for example, counts as 'cooperation' (ushirikiano), politically valorised in the tradition of community development. Amounts contributed and by whom are recorded in writing (Tripp 1994: 121-2), those made through mobile money transfer from absent participants rendered visible through whatsapp groups.

Social accountability makes contributing visible as a public action. It also protects against the secret desires provoked by cash to which almost anybody can succumb. Selfish people controlled by their own desire, tamaa, 
may display the excessive greedy associated with people thought likely to practice witchcraft (Green \& Mesaki 2005). Selfish people are said to `eat money, either stealing it, or, in hoarding it, preventing others from using it. Ideas about money and desire influence ideas about development as a project of improvement realized in better housing, the kinds of work one does and the levels of education of one's family which can be perceived as conflicting with one's duty to attend the needs of other people. Savings associations appeal here because they enable the alignment of personal aspirations for furthering one's own projects with development through collective mechanisms (Rodima Taylor 2014). Participation in newly created savings groups becomes a public performance of social and developmental responsibility. It is also a discrete arena of rule governed financial activity where contingency and indeterminacy give way to a hoped for predictability (cf Guyer 2012: 2220; Krige 2014) in a radical contrast with everyday attitudes towards and behaviours around money. 'If you stick with the system you will get money, explained an enthusiastic member of one of the longer running groups. 'You buy shares, you borrow. We get money and use money to produce money.'

\section{The VSLA Methodology}

According to CARE'S authorizing origin narrative, the VSLA model it promotes is inspired by a form of accumulating savings association (ASCA) originating within one of its projects in Niger (Allen 2002). Modified to be manageable within the project frameworks of development implementation 
the VSLA methodology combines audit practices with regular contributions and the material form of a sturdy metal box on which three padlocks can be attached- a device which, together with books in which the savings of individual group members are recorded, enables the public performance of accountability. ${ }^{10}$ Group practices are structured around the cash box supplied with financial stationery and receptacles for monies collected (Grant \& Allen 2002: 197). Members buy weekly shares up to a set limit to create a cash reserve from which they can eventually borrow. Savings accumulate through share purchase and the interest paid on loans (Anyango et al 2007: 11; Allen 2006: 62)

CARE's innovation in disseminating this form of ASCA has been to standardise the instruments through which groups are able to manage themselves and disseminate this through a package of scripted procedures and artefacts as a toolkit for group functioning. These include regular meetings, a separate 'trouble' fund for those unable to meet their contributions, designated office holding and organisational routines, in addition to rules for managing saving and lending through the public recording of group transactions (Ardener 1964: 210; Geertz 1961: 258; Bouman 1995a, 1995 b; 1997; Bouman \& Harteveld 1976: 108). Initial mobilization occurs through field agents. As groups become established and funding ends agents become private service providers, supplying kits and training for new groups and technical support, usually around shareout for existing groups (Allen \& Panetta 2010: 21-22). 
VSLA groups consist of between twelve and thirty people. Saving is a requirement of membership. Members purchase between one and five shares at weekly meetings, unless they are temporarily exempted. They also make fixed contributions to a social fund which assists members in the event of family crisis. Members can borrow up to a maximum amount, not exceeding three times the amount of the shares they have put in, for a period of three months. Interest is paid monthly. Rates vary between five and ten percent. At the end of the group cycle, generally between twelve and eighteen months, members receive what they have paid in through share purchase plus interest proportional to their shares (Maliti 2017).

Meetings follow a strict order of proceedings overseen by elected officers. Written constitutions are encouraged. Financial and personal discipline are central to group practice. Members are fined for missing meetings, for arriving late and for late payments (Maliti 2017; Malkamaki 2015: 18-19). All transactions take place in public. Transparency is enacted through the spatial organisation of the meeting in which members sit in a circle facing the cash box. The end of cycle calculation and allocation is called an 'action audit', an apt description of the accounting practices performed in public through which these groups try to make saving safe (Anyango et al 2007: 11; Allen 2006: 68; Rutherford 2009: 30). 
Despite the standardisation of formats, groups strive to differentiate themselves through motivational names like 'Jipe Moyo' (Take Heart) and 'Tuamke' (Arise). They also set some of their own rules of operation, usually fines, share prices and interest rates. Adaptability within a fixed form means that savings groups can work for a wide range of people at different ends of the income scale (Bouman 1977: 186). Appeal is somewhat limited by the short term duration of loans and the limits on borrowing. Perhaps not unrelated to this, although men are involved in savings groups in Tanzania, the majority of members are women.

\section{Saving Groups in Ulanga}

In the five years since after CARE's Access Africa project ended savings groups had a visible presence in the district. New groups were continuing to form, usually initiated by members of existing groups. Huddles of brightly clad women and a few men taking part in meetings held in the shade of homestead trees were a regular sight. Women of all ages spoke enthusiastically of going to their savings group and of juggling commitments to work and families so as to have sufficient cash to buy shares, or to be free to attend a group meeting. Because returns are limited within individual groups by the amount others actually borrow and by restrictions on the price and purchase of shares, those seeking to maximise returns on savings have to participate in several groups (Geertz 1962;245; Bouman 1979: 260; James 2015). 
Consolata, a widow in her early fifties with young adult children fifties, was a member of a single group. She earned some money from minding the small herd of goats her wealthier brother in law kept in her village and by selling leaf vegetables in the town market. Consolata wanted to `set money aside' so she could take part in 'get a cow/give a cow' dairy project organised by the agricultural office for which she needed to have money to build a cow shed. She joined a group outside her home village so that neighbours and relatives would not know how much money she was paying in or when the shareout would be.

Paulina is 62. She lives with three young grandchildren. Strong social networks are important to Paulina who is in poor health. Paulina is a member of a single group in the village where she lives. She buys one or two shares a week. Paulina only borrows the minimum in each savings cycle because it's a requirement of the group. Paulina makes `money produce money' by brewing beer every few weeks if she can afford the buy sufficient necessary maize and there is a slot in the village rota.

Charles is in his mid forties and owns a tea bar and shop serving waged workers in the town. He is the chair of a savings group called Tusaidiane (Let us help each other) which has been running for three cycles. The group has a mixed membership of town traders and farmers, of whom two thirds are women. Charles enjoys running the group as a kind of official practice which consolidates his reputation as cooperative and trustworthy(cf Ardener 
1964:221). Charles buys the maximum shares, borrows occasionally and repays quickly.

\section{'Playing' at Saving}

While groups did accommodate a range of income levels and ages, there were limits on inclusivity. People needed to have regular cash to spend of shares. Despite the hyperbolic claims of development agencies that institutional deficits hinder economic participation in rural Africa, its popular economies (James \& Hull 2014) operate through multiple financial institutions and diverse investment strategies through which people seek to gain value from `soft 'currencies (Guyer 2012). In Ulanga people with money had other ways than savings associations for money to make money, through trading in grain, pig keeping and brewing, al of which were relatively high risk and required larger up front sums than buying a few shares in a savings club. Borrowing from savings clubs for investment purposes was not that usual because of costs and because access and timeframes were not flexible. Savings associations are one of a number of options for using money productively which are considered to be very different form normal financial activity. As in other parts of Africa participation in savings associations is sometimes spoken about as 'play', a word which in Kiswahili has connotations of the regularity and restricted moves of dance and chance (Ardener 1995:7). 
Between 2012 and 2015 groups in the district's lower income communities set the price of a single share at five hundred shillings, less than fifty US cents. Groups with a greater proportion of higher income members, comprising traders and salaried workers in the district centre, set share prices up to ten times that amount. Amounts available for loans are correspondingly higher. , Whether members were low or higher income or whether groups had been formed during the original programme the savings groups appearing in villages had come to be known as 'Care groups' (Vikunde vya Care). New groups sought the expertise of people who had worked with the CARE project to produce their constitutions, a transition from project worker to self sustaining agent anticipated in a programme calculated to foster institutional sustainability (Maliti 2107). These agents also supplied the savings books, rubber stamps and cash boxes which were regarded as equipment essential to savings group operation.

Agent involvement in the setting up of new groups combined with members lack of experience of managing savings groups doubtless contributed to the standardisation of formats, and, at least in the first few years after the programme ended, homogenisation of practices among established groups (Maliti 2017: 331). Irrespective of location or the length of time they had been running, 'Care groups' in Ulanga displayed high levels of conformity to the VSLA methodology in their management of the practice of saving and in their use of regulations, procedures and artefacts. They adopted similar behaviour at meetings which displayed high levels of formality, including 
the sequencing of standardized practices and actions which were accompanied by formalized speech and refrains asserting the benefits of saving. Refrains invoked at savings groups were becoming commonplace as greetings between group members outside meetings. 'Are there shares?' 'Lots'. Or, 'You reap what you sow'.

\section{Savings Group Meetings}

The organisation of savings group meetings as a form of public event is similar to other kinds of social organising in Tanzania. Forms of oratory and office holding are elaborated in political meetings, wedding and funeral committees and the performance of official duties as public service (Falk Moore 1973; Tripp 2004;). Formalisation demarcates particular kinds of social practice and the relations it entails through the delineation of roles and responsibilities, a distinction reiterated through the organisation of time and space at savings group meetings (Dilley 2011) which centre the cash box as the focus of group activity.

Savings groups meetings are tightly choreographed events at which participants expect their behaviour to be governed by explicit rules set out in groups' constitutions, as well as inexplicit expectations regarding their presentation, dress and comportment. People dress as they would for meeting of the village assembly, the men in clean shirts and trousers, the women in bright printed fabrics, not farm clothes. As proposed in various handbooks outlining the methodology, members must ready themselves to 
pay close attention to group proceedings. They may need to respond, on penalty of a fine, to call outs from the chair or treasurer about group rules or the balance from previous meetings (Vanmeenen \& Bavois 2011; Maliti 2017). Small talk is discouraged.

Meetings are held every week at the same time and in the same place, usually he swept yard of a member's compound in the late afternoon, in the gap between finishing farm or other work, and preparing the evening meal. The space where the group is meeting is cleared to create a circle around the locked cash box placed on a low bench or table. Cash boxes used by savings groups have hasps on three sides to which padlocks can be attached so that keys can be held by different members of the group (Anyango et al 2007: 13). Keyolders (washike funguo) are ordinary, elected members of a savings group who do not hold leadership positions. They play an important role in meetings which are structured around the unlocking and relocking of the cash box.

Elected leaders of the group take their seats directly behind the cash box. Meetings follow a typical 'agenda' under the direction of a chairperson, assisted by a secretary and treasurer. All members are expected to attend. Each member has a number from one to thirty, depending on how many people are in the group. Members sit in number order in a semi circle facing the cash box. Group business is conducted through member numbers. The 
Chair, who may be male or female, opens the meeting, calling on a member to say a prayer. People bow their heads in respectful silence.

The three keyholders come forward and remove the padlocks so that the box can be opened. The treasurer and secretary reach into the box and remove its contents for all to see. These consist of a large hard bound ledger, a couple of the cheap soft bound notebooks of the kind used by school students, a large calculator, some pens, a rubber stamp and ink pad, plastic containers of different sizes with lids and a stack of booklets bound in bright colours in which members' share purchase and loans taken are recorded. The secretary takes the bundle of books and calls each person forward by their number. Members take their books and return to their places, opening them to check their balance against what they can recall from the previous meeting.

As savings books are being handed out and attendance recorded, the treasurer and secretary open the plastic tubs, removing neat bundles of worn banknotes which they count in turn. One tub is set aside for the social fund, called community (jamii) or 'disaster' (majanga) in the Tanzania groups. Another tub is used for the fines levied on members. The largest plastic container holds the balance of the group's cash which is not out on loan to members. While the money is counted and checked against the figures in the main ledger and jamii book, the treasurer may ask the group to shout out what they remember of the amounts in the box from the previous meeting. 
While the new totals are announced, group members respond with call outs and responses celebrating the actions of saving. 'Give! Give! Its rising' and 'Make savings. It will help you later'.

After the register is completed, members are called once again by number for their contribution to the social fund which is recorded in one of the exercise books as it is handed to the secretary. The next item on a typical meeting agenda is the purchase of shares (hisa) by members in number order. As each member goes to the front to hand over their money to the treasurer the number of shares purchased is announced prompting chants of affirmation- 'Give, give, its rising!' 'You reap what you sow'. The values are recorded as figures in the group ledger and as stamps in members' savings books.

The next section of the meeting deals with loan repayments Debtors come to the box to hand their money over. Arrangements for instalments and interest paid and outstanding are announced. Requests for loans come next. Finally, claims on the social fund are considered based on the rules the group has set out in its constitution. Once these are settled, the remaining cash is counted. The total cash amounts for the various funds are announced in addition to the amount which is on loan to members. Cash, sorted according to the fund it belongs to, is replaced in the plastic pots and returned to the cash box, together with members' savings books, the ledger and the notebooks, the stamp and the inkpad. The lid is closed and the key holders called forwards 
to replace the locks. Division meetings at the end of a group's saving cycle adhere to this basic structure of registration, social funds, and public calculation, except that the calculation establishes the value of members' shares and returns cash saved, along with savings books, to the members of the group. The members stand for a final prayer, the chair person announces the meeting closed. Relaxed and talking freely people disperse.

\section{Saving and Safekeeping}

As in other low income communities where the uptake of savings associations has been rapid and sustained, groups were popular because they were useful in allowing people to protect cash from the demands of kin and neighbours and to accumulate larger sums. (Bouman 1995 a 375). Some groups were extremely successful in obtaining returns for members. Others, especially those in poorer communities where there was less interest because borrowing was lower as well as share prices, could face deficits caused by defaulters which meant that the value of member shares fell rather than rose at the end of the saving cycle. For many people loan taking was exceptional rather than usual, and was oriented towards meeting family expenses, of which the most frequent were school costs and medical treatment. People who borrowed to meet household needs were likely to have difficulties meeting repayment schedules as they incurred additional costs from interest charges and fines. 
In four out of six of the Ulanga groups I interviewed, borrowing was compulsory rather then optional and was like saving, a requirement of membership. Leticia, the 34 year old chairwoman of a rural group embarking on its second cycle, explained why. 'Its necessary to borrow otherwise you are getting something for nothing. Your companions are paying something that you will get back without paying.' This justified the drastic steps needed to be taken in order to recoup defaulter's assets. 'We go to their house and we take their things, whatever they have, if they have nothing even their vyombo (everyday domestic equipment) and sell them. They have our money so their things are our property'. The logic of mutuality in which some members should not be permitted to profit at the expense of other (James 2015: 5) extended to the ways in which groups organised the purchase and resale laundry soap and sugar sold at a profit to group members. Rather than operating as a discount club which offered savings on purchases the intention is to increase members' share values by increasing the amount of money available to the group.

As in other African countries where savings associations are popular, members conceptualise their financial practices in terms of saving, rather than credit, even if they are borrowing money. Borrowing and saving are understood as ways of managing money in time, allowing people to draw down money in the present or accumulate larger sums in the future. (Shipton 1992; 1990; \& Ardener 1995: 6). This is achieved through 'saving up', in which money is set aside for future utilisation, or 'saving down', in which 
money is taken now for repayment at a later date (Rutherford 2009:16-21). From this perspective the difference between debtor or creditor status is essentially a matter of timing (Peebles 2010: 266; James 2015: 30; Maurer 2006). Consequently, non repayment of a loan may be justified by some members as an advance reclamation of their own savings (Bouman \& Haretveld 1976: 103). Such behaviour, where it occurs, allows the defaulter to take back what they have put in, but undermines the principles through which these groups have been introduced to promote saving conceptualised in terms of increasing the value of monies invested, rather than safekeeping.

Externally introduced conceptualisations of saving enmeshed within financialization narratives are very different from established systems for setting money aside and for borrowing it which have been delivered through distinct social institutions (Shipton 2014; 1992; James 2015; Roitman 2003). Saving as safeguarding of money from claims which could be made on it is prioritised over saving as a means to increase the value of money saved (James 2015; Shipton 1992; 1990: Bahre 2011: 378). What Parker Shipton refers to as an 'illiquidity preference' thus contributes to the appeal of savings associations for individual savers (1992: 29; 1990: 19; Bouman 1979: 260; 1995 : 375). This is not in actuality a financial preference determined by the place of money in social relations. It is social relations which determine the place of money and who has claims and rights to it, as well as the constitution of value (Gilbert 2005: 367 ; Zelizer 1998; 2012 ). People who participate in savings associations are seeking to temporarily instantiate different kinds 
of relations around certain kinds of money. The objective of safekeeping is problematic in savings associations where liquidity is shed through circulation on which value accumulation depends (Bouman 1995 b: 194; 1977: 194). Money placed in savings groups may be safe from oneself and the social claims of kin and neighbours but is placed at risk through its entanglement in other people's relations (Cope \& Kurtz 1980: 215; Bahre \& Smets 1999).

\section{Framing and Containing}

Savings groups set money aside in order to meet members' illiquidity preference, at the same time as money saved gains in value through flowing within and beyond the savings group. Stopping that flow periodically is necessary in order to fix relations between persons and money so as to make group assets visible and reveal what is due to savers. The practices of savings groups therefore centre on containing cash flow and on the 'framing' of transactions in which money can appear to acquire value as the effect of calculative rules (Callon 1998). Performative practices of separation and calculation which delineate between a person's individual commitments and their financial obligations to the group and between differently allocated monies within it become the focal point of savings group meetings. These are effected through the formalization of group practices and the use of instruments for the calculation and containment of currencies (Zelizer 2012: 157). 
The formalisation of practice temporarily effects the framing of saving as a processual space where money can be seen to gain value through adherence to rules of calculation performed in public which can then be inscribed in the ledgers which contain the transactions of the group. This is made possible through the dissociation of individuals from their money and the depersonalisation of members as individuals who become, temporarily, the holders of accounts (Joseph 2014; Poovey 1998: 34-42). Account holding as a status is realized at group meetings when members quite literally take hold of their account books, and, in participating in the public transactions of group business, hold each other to account. Just as persons as members become account holders through the group meeting at which their personal identities are replaced by their account number, account holders' relations with their savings books are confined to the time and space of the savings meeting. Savings books are kept together with group ledgers and cash in the locked box between meetings. The cash box is extremely important as the vehicle which quite literally brings the group together. The box symbolises the shared responsibility for savings which is effected through the practices of group members. As a container of money, membership in the form of the account books identified with individual members and the records of transactions through which returns can be calculated, the box encapsulates group activity.

The financial order of the savings groups is performed through the organisation of group meetings as an action audit, that is as the 
representation of the circulation of money and value between depersonalised accounts. It is public performance which demonstrates saving primarily as an effect of relations between group members and their money in the material form of money and abstract balances in savings books which can be attached to specific individuals. These practices strive to demonstrate that saving is an effect of accounting, that is of money gaining value through adherence to calculative rules rather than relations within and beyond group members which determine whether and how actual money from some individuals returns to others in the group (cf Keane 2001: 75). This accomplishment is tenuous. In self organised savings associations group members are simultaneously frame and flow (Callon 1998: 254). Performances of extreme compliance emphasise stability (Feldman \& Pentland 2005: 109), articulating the explicit rules of ordering which demonstrate members ' willing submission to self imposed constraints on personal and financial agency.

\section{Ritual as Organisational Practice}

The formalization in the practices of savings groups is articulated through the sequencing of standardized actions of separation and calculation which structure a rhetorical performance generative of a distinction between practices inside and outside the frame (Poovey 1998: 38; Joseph 2014; Callon 1998: 246). Such device making through repetition is characteristic of ritual which makes use of formulaic sequences of actions and utterances to discipline participants into required behaviours and to realize idistinct and 
replicable institutional forms across a range of contexts (Singleton \& Law 2013: 265, 269; Bloch 1977; Handelman 2004; Kapferer 2004; Asad 1993). Aspects of savings group practice replicate the social effects of ritual, enabling the reproduction of their practice and its re-iteration (Robbins 2009: 62-64) as the rules which comprise the formal order of accounting are embodied in practical routines.

The ritualization of savings group practices is not merely metaphoric. It is the vehicle through which groups organise themselves and the financial system which produces the effects of saving. The partial autonomy of ritual comes into play here as a device through which social orderings can be temporarily enacted and, through repetition, re-enacted ((Handleman 2004: 13). Savings associations which exploit ritual forms exhibit similar potentialities (Rodima Taylor 2014: 570). As institutional devices which enable the temporary separation and delineation of relations between persons and money, and between other people, they complement the frame making and abstraction of accounting instruments, structuring action audits as performative practice. Formalised actions for the operation of meetings, including counting and depositing money, effect the discipline essential to group functioning (Bahre \& Smets 1991). In rendering complex rules memorable and replicable, they make possible the self organising capabilities of savings groups which enables their autonomy and reproduction (Bouman 1977: 2). The `self organizing properties' of ritual accord it 
generative possibilities (Handelman 2004: 9), contributing to the speed with which these organisational forms are appropriated wherever they appear.

Village savings associations have increased in Tanzania and in places like it due to the conjunction of development programmes, the promotion of financialization imaginaries and the circulation of development travelling models of organisational forms which have claimed 'magic bullet' properties as instruments of capital accumulation (Olivier de Sardin et al 2017). Demand for participation in savings associations drives the replication of the VSLA model which is enabled through self-organisation. Self organised savings associations use ritual as an organisational device to script the regularities required to generate the routines through which the social order of saving as a rule governed relation between account holders is framed as distinct from the uncertainty and agency of everyday financial relations.

The self organisation and autonomy of savings associations contributes to the sustainability of these organisational forms beyond the life of the programmes which introduced them, at the same time as it restricts their absorption into, and hybridisation of, existing organisations. Unlike other development models whose assumed cause and effect mechanisms are undermined by the social contexts in which they are implemented, self organised savings associations create their own context in detachment from ordinary relations. John Meyer's sociological theorisation of institutional diffusion situates the circulation of modern organisational forms in the 
cultural imaginaries of the actor disseminated through globalisation. Formal organisations often have a scripted quality exhibiting a ‘ritualized affirmation of institutional form' which is loosely coupled with ostensive function (Meyer et al 2010). In the example of self organised savings associations formalisation as organisational instrument is directed at decoupling from ordinary relations. Actorhood within savings associations is achieved through restricting agency. The proliferation of savings associations, in Tanzania and elsewhere, demonstrates the productivity of formalisation as an organisational practice rather than the diffusion of formal organisations. 


\section{Acknowledgements:}

The fieldwork for this paper was carried out during a six month period in 2012, supplemented by additional shorter visits in 2013,2014 and 2015 . The initial fieldwork was funded by IDRC through a Visiting fellowship at REPOA in Dar es Salaam. I am grateful to both organizations. Permission to carry out the research in Ulanga was granted by the Tanzania Commission for Science and Technology.

I would like to thank Rafel Barua, the late Rashid Henji, Hugh Allen, Emmanuel Maliti, and Moira Eknes who generously shared their knowledge of savings associations with me and the savings group members who welcomed me to their meetings and responded to my questions. I am extremely grateful to Shirley Ardener, Erik Bahre, Deborah James, Susan Johnson, Sibel Kusimba, David Parkin, Aaron Pitluck, Maite le Polain and Tuomas Tammisito and Sibel Kusimba who provided helpful comments on earlier versions of this paper which was presented at the Development Stydies Seminar at the University of Helsinki in 2014, Financial Inclusion Research Workshop at the University of Bath in November 2015, the Society for Economic Anthropology Annual Meetings at the University of Iowa April 2016 and the Anthropology Seminar at the University of Oxford. 


\section{References Cited}

Allen, H 2002 CARE International's Village Savings and Loan Programmes in Africa. Micro Finance for the Rural Poor that Works, Care International.

Allen, H 2006 Village savings and loan associations: sustainable and cost effective rural finance, Small Enterprise Development 17 (1), 61-67.

Allen, H. and Staehle, M., 2007. How the methodology works. Village Savings and Loan Associations-A Practical Guide, 3(5), p.3.

Allen, H \& Panetta, D 2010 Savings Groups. What Are They?, Washington

DC, SEEP Network.

Anyango, E., Esipisu, E., Opoku, L., Johnson, S., Malkamaki, M. and Musoke, C., 2007. Village savings and loan associations: Experience from Zanzibar. Small Enterprise Development, 18(1), pp.11-24.

Appadurai, A., 2004. The capacity to aspire. Rao, V., and M. Walton (eds.) Culture and Public Action,, Washington DC, World Bank.. Ardener, S., 1964. The comparative study of rotating credit associations. The Journal of the Royal Anthropological Institute of Great Britain and Ireland, 94(2), pp.201-229.

Ardener, S. and Burman, S., 1995. Money-go-rounds: the importance of rotating savings and credit associations for women, Oxford, Berg. Ardener, S 2014 Credit Unions and money clubs (ROSCAs), Anthropology Today 30 (4), 3-2014 
Asad, T., 1987. On ritual and discipline in medieval Christian monasticism. Economic and Society, 16(2), pp.159-203.

Asad, T., 1993. Genealogies of religion: Discipline and reasons of power in Christianity and Islam, Baltimore, JHU Press.

Bähre, E.

2011. Liberation and redistribution: social grants, commercial insurance, and religious riches in South Africa. Comparative Studies in Society and History, 53(2), pp.371-392.

Bähre, E. \& Smets, P., 1999. Counting on people. Trust and Control in ROSCAs.

Bascom, W.R., 1952. The Esusu: A credit institution of the Yoruba. The Journal of the Royal Anthropological Institute of Great Britain and Ireland, 82(1), pp.63-69. Bloch, M., 1977. The past and the present in the present. Man, pp.278-292. Bouman, F.J., 1977. Indigenous savings and credit societies in the third world. A message, Savings and development, pp.181-219. 1994. ROSCA and ASCRA: Beyond the financial landscape. Financial Landscapes Reconstructed. The Fine Art of Mapping Development. Boulder: Westview.

1979. The ROSCA: Financial technology of an informal savings and credit insitituion in developing economies, Savings and development, pp.253-276.

1995. ROSCA: On the origin of the species. Savings and Development, pp.117-148. 
1995. Rotating and accumulating savings and credit associations:

A development perspective. World development, 23(3), pp.371-384.

Bouman, F.J.A. and Harteveld, K., 1976. The Djanggi, a traditional form of saving and credit in West Cameroon. Sociologia Ruralis, 16(1), pp.103-119.

Brown, A et al 2015 Financial Inclusion and Microfinance in Tanzania,

Cardiff, Report for DFID.

Burman, S.B. and Lembete, N., 1995. Building New Realities: African Women and ROSCAs (Rotating Savings and Credit Associations) in Urban South Africa.

Callon, M., 1998. An essay on framing and overflowing. The laws of the markets, London, Sociological Review Monograph, pp.244-269.

Cope, T. and Kurtz, D.V., 1980. Default and the Tanda: A model regarding recruitment for rotating credit associations. Ethnology, 19(2), pp.213-231.

DeLancey, M.W., 1977. Credit for the common man in Cameroon. The Journal of Modern African Studies, 15(02), pp.316-322.

Devereux, S., Pares, H. and Best, J., 1990. Credit and savings for development, Oxford, Oxfam Publications.

Dilley, R., 2011. " Daaira", Devotional Acts, and the Transformation of Space in Senegal, West Africa. Anthropos, (H. 1), pp.185-192.

Dimmagio, P. and Powell, W., 1983. The iron cage revisited: Institutional isomorphism and collective rationality in organizational fields. American Sociological Review, 48(2), pp.147-160.

Durham, D., 1995. Soliciting gifts and negotiating agency: the spirit of asking in Botswana. Journal of the Royal Anthropological Institute, pp.111-128. 
Ferguson, James. The anti-politics machine: 'development', depoliticization and bureaucratic power in Lesotho, Cambrigde, Cambridge University Press. Feldman, M.S. and Pentland, B.T., 2005. Organizational routines and the macro-actor. In Czarniawska, B. and Hernes, T (eds) , 2005. Actor-network theory and organizing, Copenhagen, Copenhagen Business School Press, 91111.

Geertz, C., 1962. The rotating credit association: A" middle rung" in development. Economic development and cultural change, 10(3), pp.241-263.

Gilbert, E., 2005. Common cents: situating money in time and place. Economy and Society, 34(3), pp.357-388.

Goffman, E., 2005. Interaction ritual: Essays in face to face behavior. Aldine, Transaction Books.

Grant, W. \& Allen, H J., 2002. CARE's Mata Masu Dubara (Women on the Move) program in Niger: Successful financial intermediation in the rural Sahel. Journal of Microfinance/ESR Review, 4(2), p.10.

Green, M., 2015. Making Africa middle class: From poverty reduction to the production of inequality in Tanzania. Economic Anthropology, 2(2), pp.295-309. Green, M., 2014. The development state: aid, culture $\mathcal{E}$ civil society in Tanzania. Boydell \& Brewer Ltd

Green, M., Kothari, U., Mercer, C. and Mitlin, D., 2012. Saving, spending, and future-making: time, discipline, and money in development. Environment and Planning A, 44(7), pp.1641-1656.

Guyer, J. 2004. Marginal gains: monetary transactions in Atlantic Africa University of Chicago Press. 
Guyer, J.I., 2012. Soft currencies, cash economies, new monies: Past and present. Proceedings of the National Academy of Sciences, 109(7), pp.2214-2221. Handelman, D 2004 Why Ritual in Its Own Right? How So?, Social Analysis 48 (2), 1-32.

Hart, K. and Ortiz, H., 2014. The anthropology of money and finance: between ethnography and world history. Annual Review of Anthropology, 43, pp.465-482.

Hendricks, L. and Chidiac, S., 2011. Village savings and loans: A pathway to financial inclusion for Africa's poorest households. Enterprise Development and Microfinance, 22(2), pp.134-146.

Hospes, O., 1992. People that count: The forgotten faces of rotating savings and credit associations in Indonesia. Savings and Development, pp.371-401. Hospes, O., 1995. Women's differential use of ROSCAs in Indonesia. In Money-go-rounds for women: rotating savings and credit associations (pp. 127-148). James, D., 2012. Money-go-round: personal economies of wealth, aspiration and indebtedness. Africa, 82(1), pp.20-40.

2014. Money from nothing: indebtedness and aspiration in South Africa. Stanford University Press. 2015. 'Women Use their Strength in the House': Savings Clubs in an Mpumalanga Village. Journal of Southern African Studies, 41(5), pp.10351052.

Hull, E. and James, D., 2012. Introduction: popular economies in South Africa. Africa, 82(1), pp.1-19. 
Joseph, M., 2014. Debt to Society: Accounting for Life under Capitalism.

University of Minnesota Press.

Kapferer, B., 2004. Ritual dynamics and virtual practice: beyond representation and meaning. Social Analysis, pp.35-54.

Kapferer, B., 1979. Introduction: ritual process and the transformation of context. Social Analysis: The International Journal of Social and Cultural Practice, (1), pp.3-19.

Keane, W 2001 Money is No Object, in Myers, F (ed) The empire of things: regimes of value and material culture, Oxford, .James Currey Publishers, 65-90. Krause, M., 2014. The good project: humanitarian relief NGOs and the fragmentation of reason. University of Chicago Press.

Krige, D 2014 Letting Money Work For Us: Self Organization and Financialisation from Below in an all Male Savings Club in Soweto, in Hart, K \& Sharp, J (eds) People, Money and Power in the Economic Crisis, New York, Berghahn, 61-81.

Kusimba, S., Yang, Y. and Chawla, N., 2016. Hearthholds of mobile money in western Kenya. Economic Anthropology, 3(2), pp.266-279.

Le Polain, M., Sterck, O. and Nyssens, M., 2018. Interest Rates in Savings Groups: Thrift or Threat?. World Development, 101, pp.162-172.

Li, T.M., 2007. The will to improve: Governmentality, development, and the practice of politics. Duke University Press.

Lugalla, J.L., 1997. Development, change, and poverty in the informal sector during the era of structural adjustments in Tanzania. Canadian Journal of African Studies/La Revue Canadienne des études Africaines, 31(3), pp.424-451. 
Maliti, E 2017. Deviation of community savings groups from their apparent methodology: Lessons from the field. International Journal of Social Economics, 44(3), pp.326-336.

Malkamaki, M., 2015. An institutional analysis of savings group development using evidence from Kenya (Doctoral dissertation, University of Bath).

Maurer, B., 2006. The anthropology of money. Annual Review of Anthropology., 35, pp.15-36.

Meyer, J.W., Drori, G.S. and Hwang, H., 2006. World society and the proliferation of formal organization. Globalization and organization: World society and organizational change, pp.25-49.

Meyer, J.W., 2010. World society, institutional theories, and the actor. Annual review of sociology, 36, pp.1-20.

Moore, S.F., 1977. Political meetings and the simulation of unanimity: Kilimanjaro 1973, in Falk Moore , S \& Myerhoff, B (eds). Secular Ritual: A Working Definition of Ritual, Amsterdam, Van Gorcum,151-173. de Sardan, J.P.O., Diarra, A. and Moha, M., 2017. Travelling models and the challenge of pragmatic contexts and practical norms: the case of maternal health. Health research policy and systems, 15(1), p.60.

Peebles, G., 2010. The anthropology of credit and debt. Annual Review of Anthropology, 39(1), p.225.

Poovey, M., 1998. A history of the modern fact: Problems of knowledge in the sciences of wealth and society. University of Chicago Press.

Robbins, J., 2009. Pentecostal networks and the spirit of globalization: On the social productivity of ritual forms. Social Analysis, 53(1), pp.55-66. 
Rodima-Taylor, D., 2014. Passageways of cooperation: Mutuality in postsocialist Tanzania. Africa, 84(4), pp.553-575.

Roitman, J.L., 2003. Unsanctioned wealth; or, the productivity of debt in Northern Cameroon. Public Culture, 15(2), pp.211-237.

Rowlands, M., 1995. Looking at Financial Landscapes: A Contextual Analysis of ROSCAs (Rotating Savings and Credit Associations) in Cameroon. Roy, A., 2010. Poverty capital: Microfinance and the making of development. Routledge.

Rutherford, S. and Arora, S., 2009. The Poor and their Money: Microfinance from a twenty-first century consumer's perspective, Oxford, Practical Action Publishing. Schwittay, A.F., 2011. The financial inclusion assemblage: Subjects, technics, rationalities. Critique of Anthropology, 31(4), pp.381-401

Shipton, P., 1992. The rope and the box: Group savings in The Gambia. Informal Finance in low-income countries, pp.25-41.

Shipton, P.M., 2010. Credit Between Cultures: Credit Between Cultures: Farmers, Financiers, and Misunderstanding in Africa. Yale University Press.

Singleton, V. and Law, J., 2013. Devices as rituals: notes on enacting resistance. Journal of Cultural Economy, 6(3), pp.259-277.

Strang, D. and Meyer, J.W., 1993. Institutional conditions for diffusion. Theory and society, 22(4), pp.487-511.

Thomassen, B., 2012. Notes towards an anthropology of political revolutions. Comparative Studies in Society and History, 54(3), pp.679-706. 
Tripp, A.M., 1994. Gender, political participation and the transformation of associational life in Uganda and Tanzania. African Studies Review, 37(1), pp.107-131.

Vanmeenen, G \& Bavious M 2011 SILC Field Agent Guide, Catholic Relief Services.

Watanabe, C., 2015. Commitments of debt: temporality and the meanings of aid work in a Japanese NGO in Myanmar. American Anthropologist, 117(3), pp.468-479.

Zelizer, V.A., 1989. The social meaning of money:" special monies". American journal of sociology, pp.342-377.Zelizer, V.A., 1998. The proliferation of social currencies1. The Sociological Review, 46(S1), pp.58-68.

Zelizer, V.A., 2012. How I became a relational economic sociologist and what does that mean?. Politics $\mathcal{E}$ Society, 40(2), pp.145-174. 


\section{Notes}

${ }^{1}$ In 2012 an estimated 14.5 million people were members of savings associations initiated by development programmes (Malkamaki 2015:17).

2 The same model for savings association practice is currently used by CRS, Oxfam, PACT, Plan International and Aga Khan Foundation, as well as CARE International (Malkamaki 2015: 17).

${ }^{3}$ Groups organised in this way pool labour, building materials, foodstuffs and cash (e.g. Hospses 1995;Ardener 1964).

${ }^{4}$ For a critique of this position see Ardener (1964).

${ }^{5}$ For example participation in savings groups features in the national cash transfer programme implemented through the Tanzania Social Action Fund (TASAF). Savings groups have received funding through the National Economic Empowerment Council http:/ / www.thecitizen.co.tz/News/Business/Vicoba-role-set-to-come-intofocus/1840414-4100610-fjnhz/index.html

${ }^{6}$ Village and Community Bank (VICOBA) used by the Swedish International Development Agency (SIDA) and Savings and Internal Lending Community, used by Catholic Relief Services (Allen et al 2010).

${ }^{7}$ According to the Citizen newspaper article from July $5^{\text {th }} 2016$, there were over 100,000 savings groups http:/ / allafrica.com/stories/201607060353.html

9 The population of the new Ulanga District after it was divided into Ulanga and Malinyi Districts in 2015. 
10 The cash boxes were developed within the original Niger Care programme.

The original boxes had hasps at the front of the box. Personal communication Moria Eknes. 